Per Ledin

Professor i svenska språket

Örebro universitet

\title{
Listans och tabellens semiotik
}

\begin{abstract}
This article has a theoretical aim and explores the semiotics of lists and tables. It takes a historical perspective and looks at both the invention of writing (phylogeny) and the writing development of the child (ontogeny) in order to uncover how meaning-making evolves through the use of semiotic and material resources. Lists on clay followed the invention of writing and were used for bureaucratic purposes, to plan and take control over e.g. food, persons and words, which we recognize in today's grocery lists, participant lists and word lists. When literacy grows and elaborated classification systems are codified, the table becomes an important semiotic tool that enables detailed and systematic comparisons by its use of materiality, where columns and rows intersect and linguistic and numerical signs can be combined. At the end of the article, I synthesize my observations in a model that shows what kind of meaning-making lists and tables are apt for.
\end{abstract}

\section{Sammanfattning}

Huvudsyftet med denna artikel är teoretiskt. Jag undersöker listans och tabellens semiotik och visar vilket meningsskapande listor och tabeller lägger upp för. För att förstå listan och tabellen går jag både till skriftens uppkomst hos människan (fylogenesen) och skriftens utveckling hos barnet (ontogenesen). På så vis kan jag belysa hur dessa semiotiska verktyg ur ett historiskt och materiellt perspektiv blivit lämpade för vissa men inte andra sorters meningsskapande. Listor på lertavlor används tidigt för byråkratiska syften, för att överblicka och kontrollera exempelvis mat, personer eller ord, vilket vi känner igen från dagens handeller datorskrivna matlistor, deltagarlistor och ordlistor. När en mer avancerad reglering eller kunskap tar form är tabellen ett verktyg som tillåter exakta och systematiska jämförelser utifrån sin alldeles bestämda materialitet, där kolumner och rader korsas och språkliga och numeriska tecken gärna kombineras. Artikeln avslutas med att jag syntetiserar mina iakttagelser $i$ en semiotisk modell.

När människan uppfinner skriften för 5000 år sedan kan man tro att det är fängslande berättelser, levnadsöden och betraktelser som ser dagens ljus. Men så är det inte. Det vi får är listor som förtecknar olika saker. Detta är den enklast tänkbara sakprosan, förteckningar över saker och ting, och det är i den sakprosan som skriftkulturer har sin grund. Utifrån listor och seder- 
mera tabeller kan byråkratier utvecklas, invånare kontrolleras och stater bildas. Även för det barn som växer upp idag kommer listan att vara en central textform. Den kan i barnets skrivande komma till uttryck som en önskelista eller en att göra-lista. Den kommer att vara en bas för vad som händer i skolan men är också den form som den som vill göra en PowerPointpresentation har att utgå från.

Huvudsyftet med denna artikel är teoretiskt. Jag vill utreda listans och tabellens semiotiska egenskaper, alltså vilket slags meningsskapande som listor och tabeller lägger upp för. Det gör jag genom att först belysa hur listan och tabellen utvecklas ur ett fylogenetiskt och ontogenetiskt perspektiv. För att förstå listan och tabellen kommer jag att gå både till skriftens uppkomst hos människan (fylogenesen) och skriftens utveckling hos barnet (ontogenesen). Tidigare forskning - som är knapphändig - redovisar jag allt eftersom. Jag föreslår sedan en semiotisk modell för listor och tabeller. Den huvudsakliga motiveringen för artikeln är att listor och tabeller, trots att de är kraftfulla semiotiska verktyg, inte rönt någon större uppmärksamhet från språkvetare och semiotiker.

Min ansats belyser det som Kress (2010) kallar affordances, vilket innefattar de möjligheter och begränsningar som olika semiotiska verktyg har, inte minst ur ett historiskt och materiellt perspektiv (jfr Björkvall, 2012). Semiotiska resurser (som skriftspråk, räknesystem, olika slags bilder) utvecklas historiskt så att de kombineras och materialiseras på bestämda sätt. De blir till semiotiska verktyg, lämpade för vissa men inte andra sorters meningsskapande. Listor på lertavlor används tidigt för byråkratiska syften, för att överblicka och kontrollera exempelvis mat, personer eller ord, vilket vi känner igen från dagens hand- eller datorskrivna matlistor, deltagarlistor och ordlistor. När en mer avancerad reglering eller kunskap tar form är tabellen ett verktyg som tillåter exakta och systematiska jämförelser utifrån sin alldeles bestämda materialitet, där kolumner och rader korsas. Vi kan ta en nutida jämförelse av bilar som exempel. Använder vi tabellen som semiotiskt verktyg kan vi till vänster lista bilmärken och sedan i på varandra följande kolumner bränsleförbrukning, säkerhetsklassificering, pris etc., vilket gör det möjligt att se vad som är för- och nackdelar med olika märken.

\section{Paradigm, syntagm och meningskapande}

För att få en ingång till listans och tabellens affordances och deras historiskt framvuxna semiotik, ser vi närmare på de paradigmatiska och syntagmatiska relationerna i meningsskapande. Termerna har utvecklats inom den europeiska 1900-talsstrukturalism som Ferdinand de Saussure lägger grunden till i sin Kurs $i$ allmän lingvistik (1970 [1916]). Saussure säger att paradigmatiska (med hans ord "associativa") och syntagmatiska relationer "motsvarar två former av vår mentala aktivitet, som båda är oundgängliga för språkets liv" (s. 155). Som paradigm ser han ord "med någonting gemensamt". Utanför talet associeras de "i minnet och på så sätt bildas grupper, inom vilka olika förbindelser råder". Saussure exemplifierar med det franska ordet enseignment, 'undervisning', och säger att det framkallar andra ord som på ett eller annat sätt är besläktade. Ord har också "förbindelser grundade på språkets lineära natur, eftersom de är kedjade vid varandra". Kombinationer "som bygger på lineariteten kan kallas syntagmer". Språk uppträder i talet som räckor av ord. 
För Saussure är paradigm, eller associativa relationer, det som främst utmärker språket, langue, som förstås som ett formellt system av skillnader. Även om syntagmatiska relationer kan ingå i langue, så ligger de närmare det faktiska talet, dvs. det som Saussure kallar parole och ser som så varierat att det omöjligt kan ingå i språkvetenskapen. Detta tar Roland Barthes (1967) upp till diskussion i sin Elements of Semiology, där han bland annat visar hur kläder och mat kan förstås semiotiskt. Paradigmatiska relationer innebär att företeelser hör samman. Det kan handla om klädesplagg, som skiljs ut i paradigm enligt principen att de "cannot be worn at the same time on the same part of the body, and whose variation corresponds to a change in the meaning: toque - bonnet - hood, etc.” (1967:63). Här utgör alltså toque, bonnet och hood ett paradigm, eftersom de alla är huvudbonader, och vi får tänka oss att pumps, gympaskor och gummistövlar på samma sätt är ett paradigm som hör samman med fötterna. De val vi gör inom paradigm realiseras syntagmatiskt, som kombinationer av klädenheter som vi har på olika delar av kroppen.

Barthes tolkning av Saussure kommer fortfarande tillbaka i semiotiskt inriktade läroböcker. I figur 1 visas Frandsen, Johansen \& Ellerup Nielsens (1997:45) illustration av principerna för kläders grammatik, alltså för hur kläder väljs och kombineras. Det paradigmatiska meningsskapandet, selektionsaxeln, utgörs av den uppsättning av samhöriga klädesplagg som ett val görs utifrån och beskrivs vertikalt. Det syntagmatiska meningsskapandet, kombinationsaxeln, blir en faktisk kombination av enheter eller plagg och uttrycks horisontellt. Liksom hos Saussure tenderar systemet att bli den uppsättning paradigm som uppstår genom de systematiska skillnader som görs i en kultur. En syntagm tenderar att bli realiseringar av detta system: hur kläder från olika paradigm kombineras och används av någon.

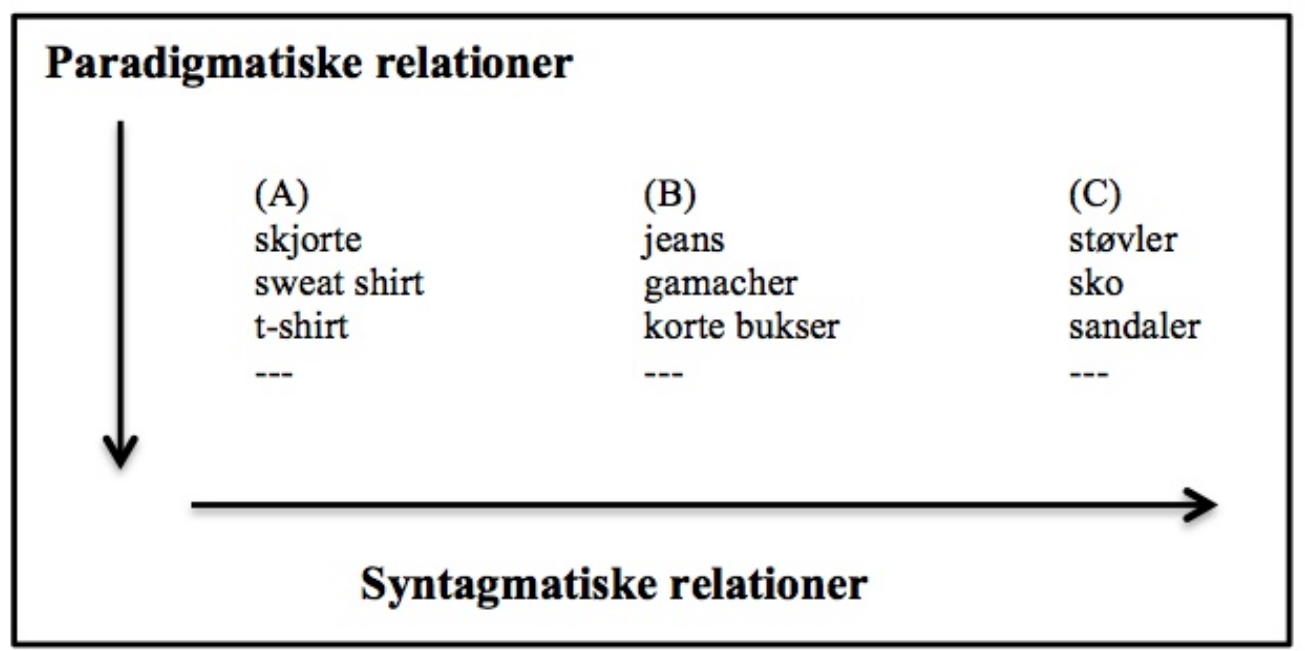

Figur 1. Frandsen, Johansen \& Ellerup Nielsen (1997:45) illustrerar Barthes (1967) modell för kläders grammatik, där paradigmatiska relationer (på en selektionsaxel) kombineras med syntagmatiska relationer (på en kombinationsaxel).

Det är vanligt att se paradigmatiska relationer som vertikala och syntagmatiska som horisontella. Detta kan relateras till listans och tabellens materialitet, där det vertikala och horisontella blir rumsliga dimensioner. Listans paradigmatiska karaktär gör att den kan (men inte måste, som vi ska se) skrivas vertikalt, uppifrån och ner. Tabellens syntagmatiska karak- 
tär gör att den måste få en horisontell utsträckning och innehålla rader, som utgör kombinationer av enheter från olika paradigm.

För en förståelse av listan och tabellen är materialiteten en huvudsak. Hodge \& Kress (1988:20) talar i sin socialsemiotik om en "materialist structuralism", vars rötter finns hos Vološinov (1986 [1929]), som var samtida och samarbetade med Bachtin. I Vološinovs omläsning och kritik av Saussure framhålls tecknets materialitet på ett radikalt sätt: "consciousness itself can arise and become a viable fact only in the material embodiment of signs" (1986:11, originalets kursiv). Det är i och genom sådant som är materialiserat - i vårt fall listan och tabellen - som vi, i samspel med andra, utvecklar ett mer avancerat tänkande och handlande $\mathrm{i}$ en kultur: "It is not experience that organizes expression, but the other way around - expression organizes experience" (1986:85). Även i Ledins (2013) diskussion av textbegreppet blir materialiteten avgörande. En text är i sin enklaste form en inskription, gjord med ett visst teckensystem, på ett material. Ser vi på listor är det uppenbart att de genom historien använt sig av olika materialiteter: lertavlor, pergament, papper, datorskärmar etc. Det är också uppenbart att olika teckensystem tas i bruk. Språkliga tecken samsas gärna med matematiska tecken, så att ord avlöses av siffror.

Den teoretiska utgångspunkten för denna artikel är socialsemiotisk, så att listor och tabeller ses som materiella fenomen, designade för ett visst meningsskapande, och med vars hjälp ett avancerat tänkande och handlande uppstår i kulturella praktiker. Det tänkandet och handlandet har sin grund $i$ att ett paradigm materialiseras, att kulturellt samhöriga kategorier listas och då separeras, abstraheras och reifieras. Hodge \& Kress (1988:30) uttrycker det så: "The source of the features of a paradigmatic structure $[\ldots]$ is the material world of human actions and purposes in space and time."

Att en sådan här semiotik inte behöver utesluta en poetik visar Eco (2009) som lägger listan till grund för estetiska iakttagelser av konst och litteratur. Att lista och förteckna tycks höra till människans natur, vara hennes sätt att nagla fast världen, både den värdsliga och bortomjordiska tillvaron - om det så är alla kretsar i helvetet eller alla änglar i himlen. Detta kan aldrig lyckas helt; den definitiva listan finns inte. För Eco är det naturligt att något hamnar utanför, glöms bort eller inte kan sägas.

\section{Fylogenes: listan, tabellen och skriftens uppkomst}

Vi vet inte säkert när människans språk- och talförmåga uppstod i evolutionen, men det är åtminstone 200000 år sedan (jfr Gärdenfors, 2007). Med språket kommer efter hand nya semiotiska verktyg och teknologier. Ser vi till människans användning av inskriptioner, av tecken inskrivna i ett material, olika ristningar, daterar den sig åtminstone 60000 år tillbaka $i$ tiden (Säljö, 2012:237). Skriften har en grund i övergången från jägar- till jordbrukssamhälle i olika delar av världen för omkring 12000 år sedan. Det medförde att befolkningen ökade kraftigt och blev bofast. Samhällssystem började utvecklas, så att skördar, mark, bevattningsanläggningar etc. kunde ägas och fördelas (t.ex. Jansson, 1997; Melin, 2000; Reade, 2000).

Det första skriftsystemet uppstod för ca 5000 år sedan i Mesopotamien, hos sumererna i Eufrat och Tigris bördiga floddalar, där uppfinningar som hjulet och plogen gjort att skör- 
darna gav ett överskott. Skriftsystemet kallas kilskrift, och det materialiserades på lertavlor (Coulmas, 1989:72ff.). Kilskriften kom att utvecklas från ikoner till symboler, från piktografiska tecken till stavelsetecken. Utvecklingen gick sedan vidare till ljudbetecknande former, så att det vi kallar bokstäver uppkommer. Dagens alfabet, den uppfinning som givit upphov till termen literacy (efter latinets litera, 'bokstav'), uppfanns av grekerna för omkring 3000 år sedan. Det finns tydliga kopplingar tillbaka till tidigare skriftsystem i Främre Asien. Bokstaven A går exempelvis att känna igen från det ursprungligen piktografiska kilskriftstecknet för oxe, med beteckningen aleph i det feniciska alfabet som föregick det grekiska (Coulmas, 1989:163).

Tidigt användes olika slags objekt, bilder och enkla tecken för att ordna samhället. Exempelvis blev räknestenar viktiga när jordbruket uppstod. De bestod från början av småstenar eller bakade lerklumpar och användes för bokföring och beräkning. Relationen mellan det enkla tecknet (stenen) och referenten byggde på korrespondens. En sten motsvarade ett objekt, en viss vara, och stenarna lades i olika stora lerbehållare, som användes för affärskommunikation. Behållaren kunde fraktas till en bokhållare eller fungera som betalning i en affärsuppgörelse. Det här kom att utvecklas och ge upphov till sekundära tecken och koder behållaren kunde lämnas utan stenar, tecken som refererar till behållare uppstod etc. - så att ett regelrätt räknesystem uppstod. På samma sätt kom piktogram att blir abstrakta. De kom att glida ifrån den direkta och ikoniska avbildningen av ett objekt och i stället utvecklas till en abstrakt kod med stavelsetecken (Coulmas, 1989:23ff.).

Mot denna bakgrund är det inte förvånande att de tidigaste sumeriska texterna är just listor. Exempel 1 visar en sumerisk lertavla från omkring 3000 f.Kr. Den förtecknar tilldelningen av öl - öl var sumerernas favoritdryck och användes som betalning till arbetare vid tempelbyggen. Skriften är vid den här tiden fortfarande piktografisk, så att öl symboliseras av en kruka med en avsmalnande botten. De i leran nedsänkta cirklarna och skärorna vid sidan om krukorna är numeriska tecken, och längst ner till vänster finns en skål som är lutad mot ett skissartat ansikte, vilket är symbolen för att äta eller dricka. Lertavlorna lästes uppifrån och ned vid den här tiden; först senare skulle en horisontell läsning utvecklas. Tecknen ramas in i celler, vilket visar att det är likadana enheter som räknas upp. Att urskilja komponenter eller delar av något på detta sätt är vanligt även idag, vilket Kress \& van Leeuwen (2006: kap. 3) visar i sin semiotiska genomgång av vad de kallar analytiska processer. I reklamannonser eller läroböcker kan materialiteten formateras i rutmönster där likadana delar, enheterna i ett paradigm, placeras och därmed samordnas.

De tidigaste listorna är ofta av det här slaget, dvs. de använder piktografiska tecken och förtecknar lagringen eller tilldelningen av olika slags jordbruksvaror. Det är värt att notera att tidiga listor gärna kombinerar semiotiska resurser, mer exakt ord och siffror, vilket ger dem får vissa tabellegenskaper. De både anger objekt (här öl) och kvantifierar dem (mängden öl) med hjälp av olika teckensystem och i en materialitet som skiljer ut varje kvantifierat objekt. 


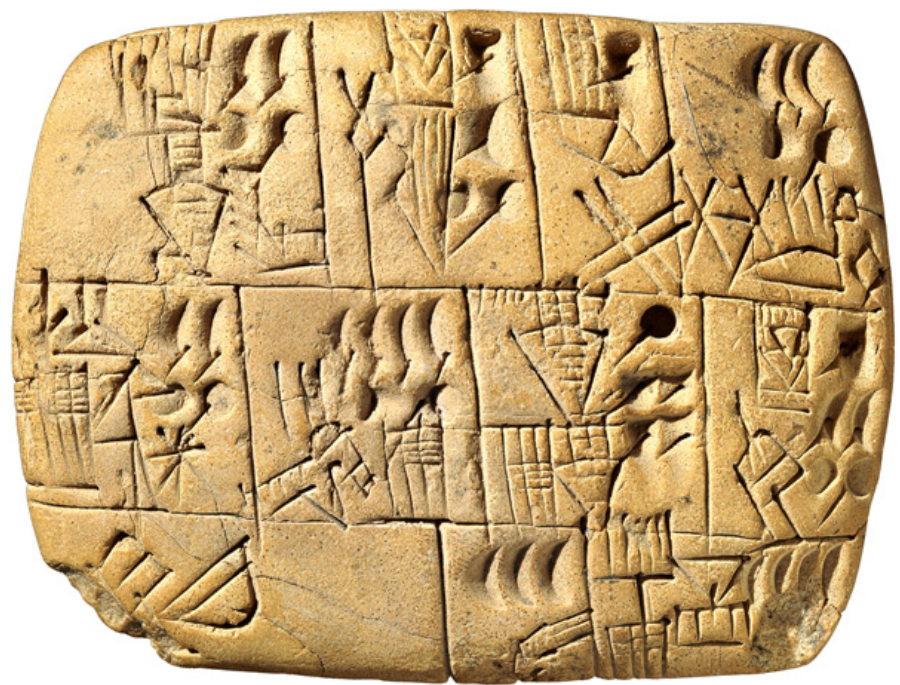

Exempel 1. Sumerisk lista som förtecknar tilldelning av öl från ca 3000 f.Kr, hämtad från British Museum, http://www.britishmuseum.org/explore/highlights/highlight_objects/me/t/tablet,_allocation_of_beer.aspx (jfr Reade, 2000:36).

Ett verk som tydligt skriver fram listan som en grund för skriftens utveckling är Jack Goodys (1977) The Domestication of the Savage Mind. Goody (1977:81) menar att listan gör att språkliga enheter separeras och abstraheras. En lista "encourages the ordering of the items, by number, by initial sound, by category, etc. And the existence of boundaries, external and internal, brings greater visibility to categories, at the same time as making them more abstract." I en ekonomi som den sumeriska där stora tempel och palats uppfördes var det mycket som behövde förtecknas, exempelvis

income taxes, tribute, and the yield of the royal or priestly domain and workshops as well as the distribution of materials and ransons to craftsmen and workers, a type of recording which was 'strictly formalized and astutely co-ordinated', and which was very much in evidence wherever writing on clay has led to the preservation of early documents. (Goody, 1977:82f.)

Den administrativa listan beskriver Goody som huvudsakligen retrospektiv, som en förteckning över befintliga personer, objekt eller händelser. De enklaste listorna bygger, precis som de tidiga räknestenarna, på korrespondens mellan tecknet och referenten, som är fysiskt tillgänglig och kan vara exempelvis öl, vete eller korn. Tidiga listor är alltså, konstaterar Fernandez (1991:32), kopplade till en mycket enkel läs- och skrivfärdighet, till "minimum decoding".

En från början ovanlig men allt eftersom spridd lista är den lexikala, som ska ses som "a protodictionary or embryonic encyclopaedia" (Goody, 1977:80). När stavelseskriften började bli utvecklad uppstod olika morfologiska listor, ordnade efter stavelser och motsvarande de alfabetiska listor vi känner igen från vår kultur. De kunde exempelvis baseras på vokalljud i stavelserna eller på teckenformen. Andra listor var begreppsliga och sorterade in objekt i kategorier: olika slags träd, växter, delar av kroppen osv. Sådana listor blev viktiga i det skolsystem som var tvunget att utvecklas för att garantera att en elit kunde läsa, skriva och räkna. De etablerar och organiserar kulturella erfarenheter och skapar en beständig kunskap som kan 
traderas. Paradigmen bygger då inte längre på objekt som är tillgängliga i den aktuella situationen. De är en produkt av språket och skriften i sig och får karaktär av klassifikationssystem.

I boken All verdens kunnskap (Nasjonalbiblioteket, 2012) tas lexikonets och encyklopedins utveckling under 2000 år upp. Det första försöket att samla all världens vetande var Plinius' naturhistoria, Naturalis historia, som författades under det första århundradet av vår tideräkning. Verket består av 37 böcker som är tematiskt ordnade efter matematik, kosmologi, geografi, etnografi, medicin etc. Renodlat alfabetiska uppslagsböcker kommer med 1700talets stora encyklopedier, inte minst Diderots och d'Alemberts Encyklopédie, som började utges 1751. Den alfabetiska principen väckte uppseende, och myndigheterna motarbetade encyklopedin och dess strikta, sekulariserade listning. Men bokstavsordningen sågs som den enklaste och effektivaste principen när all världens kunskap skulle sammanställas och göras komplett. Så kunde kultur och natur, det gudomliga och det världsliga, högt och lågt, inordnas i ett och samma klassifikationssystem (Nasjonalbiblioteket, 2012:17ff.).

Går vi tillbaka till det tidiga skriftbruket så blir listorna mer komplexa. Två samhöriga listor från den dåvarande syrianska hamnstaden Ugarit, daterade 1400 f.Kr., har följande innehåll:

Men arranged in two lists; the first list give the name of each man mentioning weather he has a wife and child; men without wives have their locality indicated, or, in the last entry, the man's trade; the second list enumerates the king's personell telling weather each man has a wife and child, and in an instance where he has none his trade is stated. (Goody, 1977:89)

De två listorna beskriver män i Ugarit utifrån civilstånd, barn, om ogift man även plats eller yrke plus vittnesbörd från kungens män om dessa kategorier. Listor kan alltså användas för att ge information om någon eller något ur ett bestämt antal aspekter, vilket $\mathrm{i}$ vår tid är grafiskt systematiserat i tabeller med kolumner och rader.

För att skriften ska möjliggöra byråkrati behövs det arkiv. När systematiskt ordnad information om personer, objekt, begrepp osv. kan arkiveras kan sådant som skatter, skolor, anställda eller affärsuppgörelser hanteras administrativt. Låt oss hoppa framåt i tiden, till det medeltida England, som beskrivs i Michael Clanchys (2013) From Memory to Written Record. Clanchy tar sig an perioden från Wilhelm Erövrarens seger vid Hastings 1066 till Edward I:s död 1307 och visar hur en skriftkultur tar form i och med att arkiv systematiskt byggs upp runt om i landet.

En del av den processen är att det skrivna ordet börjar bli mer tillförlitligt än det muntliga ordet. Som ett exempel på övergången från muntligt till skriftligt tar Clanchy (2013:277) en rättegång 1293 mot en viss Hugh, som anklagades för våldtäkt. Hugh gjorde gällande att det fanns jäviga jurymedlemmar som han låtit författa en lista över. Domaren bad honom läsa upp sina anklagelser. Hugh blev perplex: "Jag kan inte läsa." Domaren förklarade att inte heller han kunde läsa upp listan, eftersom orden måste komma ur Hughs mun. Till sist blev det så att Hughs försvarare fick viska anklagelserna på listan i Hughs öra så att det blev hans ord. Clanchy noterar att de tidigare muntliga reglerna för hur jurymedlemmar ifrågasätts nu blivit skriftliga; en skriven lista skulle tvunget upprättas och inlämnas till rätten. Samtidigt var 
skriftligheten inte så långt gången att dokumentet i sig var tillräckligt. Det var nödvändigt att anklagelserna gavs röst av just den som framförde dem.

På 1200-talet kom centralmakten att utöka sina arkiv och därmed byråkratin. En spridd visa var Song of the Husbandman, där kyrkans män tar upp skatt av bönderna (Clanchy, 2013:48). Skatteindrivaren förklarar: "Du står i min lista, som du mycket väl vet." På fornengelska: Thou art written y my writ that thou wel wost. Lokala arkiv inrättades och kungen ålade fogdar att förteckna invånarna, inte minst i beskattningssyfte. I exempel 2 visas övre delen av en förteckning över handlare från 1226-1227, upprättad i Wellingfords köping (se tablå 9, utan sidnumrering, i Clanchys bok). Materialiteten är pergament, som kunde rullas ihop och förvaras.

Det här är en tabell. Allra längst vill vänster urskiljs två grupper, handskmakare och tygmakare. Listan fortsätter sedan med slaktare, snickare, smeder etc. Detta är vad Goody kallar en lexikal lista, där paradigmet med handlare delas in i bestämda kategorier, så att ett klassificeringssystem uppstår som täcker in dem med en sådan yrkesutövning. I varje kategori kan sedan personerna i Wellingford förtecknas. Exempelvis nämns på den tredje raden handskmakare Roger the Clothier, som är skyldig 16 pence ,"xvi.d.", som det står i den följande kolumnen. Till höger finns sedan tre kvitteringar, där de summor som Roger the Clothier erlagt har noterats av tre olika händer/skrivare: 4 pence, "r. iiij .d." ("r" ska utläsas som "recieved"), 6 pence och 6 pence, följt av "quit", som markerar att allt är betalt.

Exempel 2. Tabell med handlare i Wellingfords köping från 1226-1227, hämtad från tablå 9 i Clancy (2013) - tablån ligger som en sorts bilaga utan sidnummer efter huvudtexten.

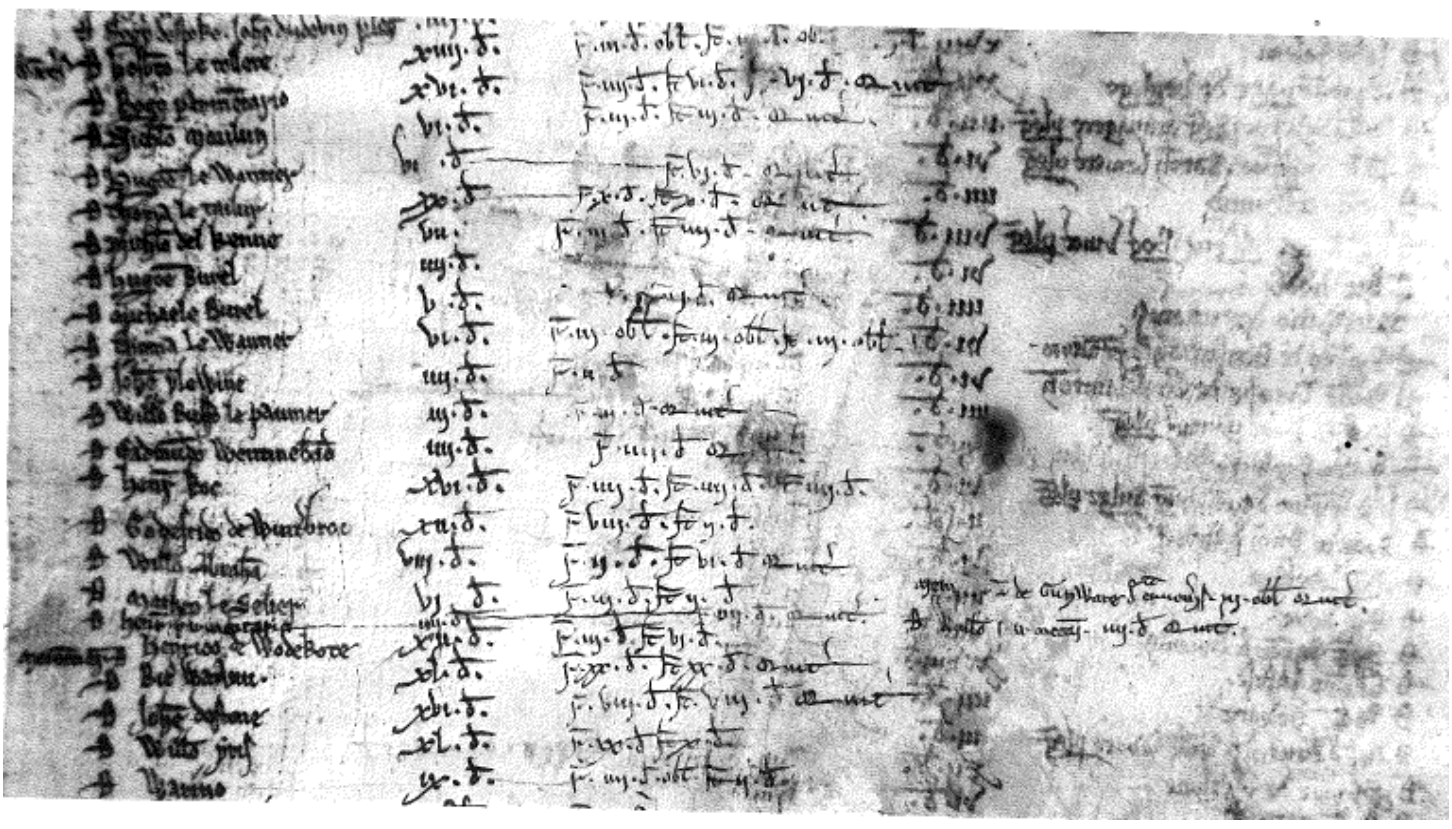

Detta visar att tabeller kan vara öppna och interaktiva, att det till deras affordances hör att de kan ha bäring på och kräva framtida handlingar. Den här tabellen är ett kraftfullt semiotiskt verktyg och fungerar både som en personlista, där befintliga affärsmän grupperas efter yrke, och som en kvittensbok, där erlagd skatt registreras. Denna syntagm eller tabellrad fylls på 
tills skatten är betald, och den ser likadan ut för alla affärsidkarna i Wellingford. Det krävs att så sker, att varje handlare betalar det han ska, annars blir han av med sina affärsrättigheter. Vi ser också att tabeller bygger på att ett visst paradigm görs till utgångspunkt för systematiska jämförelser, i vårt fall personer inom yrkeskategorier. Att det paradigmet blir utgångspunkten realiseras semiotiskt genom att det listas längst till vänster som given information.

I det tidigmoderna Europa blir tabellen viktigare och klassifikationssystemen mer elaborerade. I exempel 3 visas en mycket utförlig tabell över folkslag i Europa från början av 1700-talet, hämtad från Goody (1977:154f.), som i sin tur hämtat den från ett österrikiskt original som heter Beschraibung und Konterfei der Europäischen Nationen.

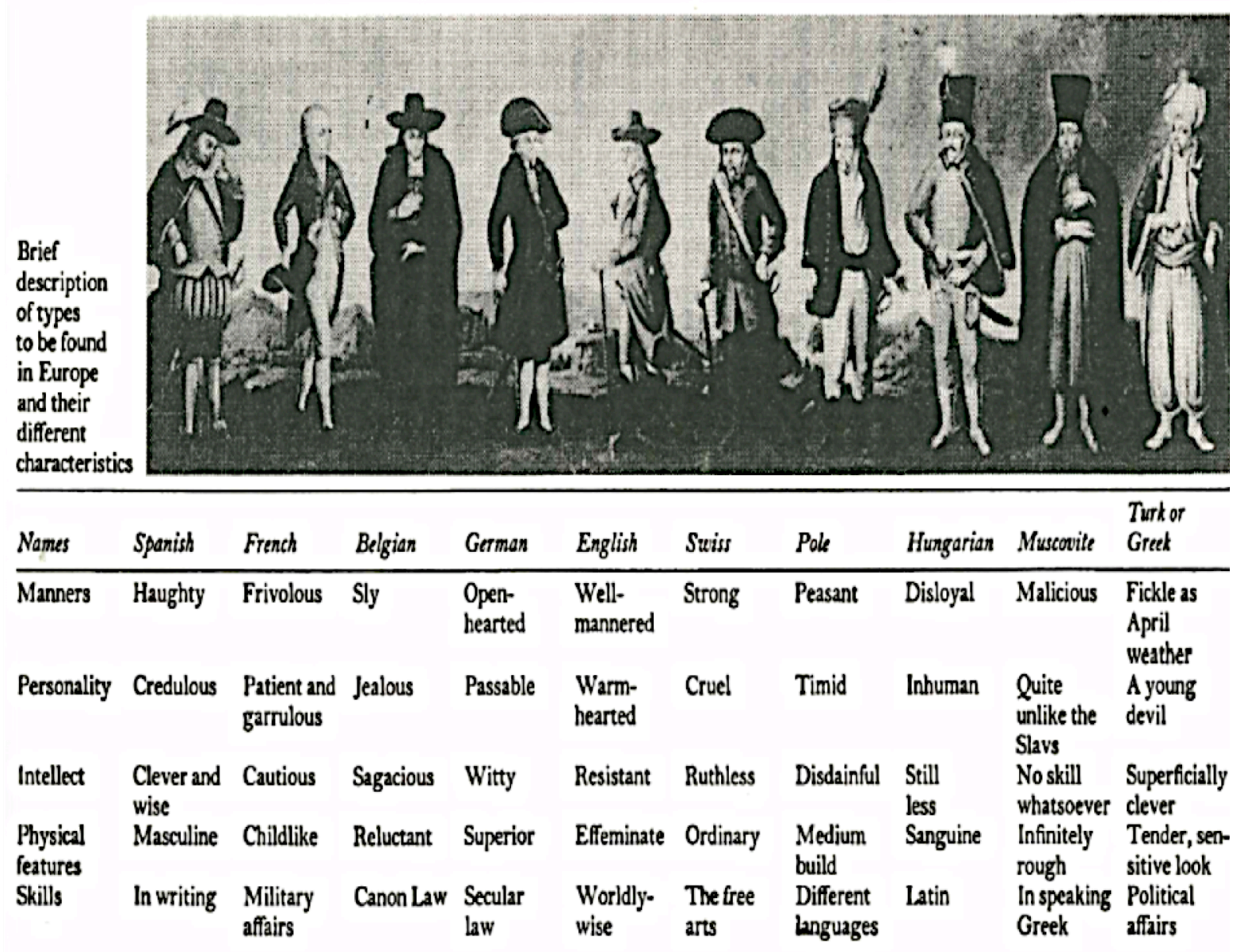

Exempel 3. Tabell över Europas nationer (hämtad från Goody 1997:154f.) 


\begin{tabular}{|c|c|c|c|c|c|c|c|c|c|c|}
\hline Names & Spanish & French & Belgian & German & English & Swiss & Pole & Hungarian & Muscovite & $\begin{array}{l}\text { Turk of } \\
\text { Greek }\end{array}$ \\
\hline Costume & Respectable & Variable & Respectable & $\begin{array}{l}\text { Slaves to } \\
\text { fashion }\end{array}$ & Frenchified & Fustian & $\begin{array}{l}\text { Long- } \\
\text { skirted }\end{array}$ & $\begin{array}{l}\text { Very } \\
\text { colourful }\end{array}$ & Chains & Like women \\
\hline Faults & Haughty & Deceitful & Randy & $\begin{array}{l}\text { Extrava- } \\
\text { gant }\end{array}$ & Restless & Credulity & Braggart & $\begin{array}{l}\text { Treacher- } \\
\text { ous }\end{array}$ & Windbags & $\begin{array}{l}\text { Even greater } \\
\text { windbags }\end{array}$ \\
\hline Likes & $\begin{array}{l}\text { Flattery } \\
\text { and praise }\end{array}$ & Warfare & Gold & Drink & Voluptuous & $\begin{array}{l}\text { Expensive } \\
\text { food }\end{array}$ & $\begin{array}{l}\text { The } \\
\text { aristocracy }\end{array}$ & $\begin{array}{l}\text { Causing a } \\
\text { disturbance }\end{array}$ & Little figs & Self-love \\
\hline Diseases & $\begin{array}{l}\text { Con- } \\
\text { stipation }\end{array}$ & $\begin{array}{l}\text { Peculiar to } \\
\text { themselves }\end{array}$ & The plague & Bodagra & $\begin{array}{l}\text { Con- } \\
\text { sumption }\end{array}$ & Colic & Rupture & Influenza & Asthma & Anaemia \\
\hline $\begin{array}{l}\text { Their } \\
\text { country }\end{array}$ & Fertile & $\begin{array}{l}\text { Well- } \\
\text { cultivated }\end{array}$ & Pleasant & Good & Fertile & $\begin{array}{l}\text { Moun- } \\
\text { tainous }\end{array}$ & Wooded & $\begin{array}{l}\text { Fertile and } \\
\text { rich in } \\
\text { minerals }\end{array}$ & Full of ice & Pleasant \\
\hline War virtues & Courageous & $\begin{array}{l}\text { Machiavel- } \\
\text { lian }\end{array}$ & Cautious & Invincible & $\begin{array}{l}\text { Heroes at } \\
\text { sea }\end{array}$ & $\begin{array}{l}\text { Passionate } \\
\text { commitment }\end{array}$ & Uncertain & Like pirates & $\begin{array}{l}\text { Well- } \\
\text { organised }\end{array}$ & Lazy \\
\hline Worship & $\begin{array}{l}\text { The best of } \\
\text { everything }\end{array}$ & Goodness & $\begin{array}{l}\text { A little } \\
\text { better }\end{array}$ & $\begin{array}{l}\text { Still more } \\
\text { pious }\end{array}$ & $\begin{array}{l}\text { Fickle as } \\
\text { the moon }\end{array}$ & $\begin{array}{l}\text { Busy } \\
\text { beehives }\end{array}$ & $\begin{array}{l}\text { Believe all } \\
\text { manner of } \\
\text { things }\end{array}$ & Activity & Apostate & The same \\
\hline $\begin{array}{l}\text { Their } \\
\text { master }\end{array}$ & A monarch & A king & A patriarch & A kaiser & $\begin{array}{l}\text { Now one, } \\
\text { now the } \\
\text { other }\end{array}$ & Frechold & $\begin{array}{l}\text { Somebody } \\
\text { elected }\end{array}$ & $\begin{array}{l}\text { The } \\
\text { unlovable }\end{array}$ & Volunteer & A tyrant \\
\hline Excesses of & Fruits & $\begin{array}{l}\text { Mer- } \\
\text { chandise }\end{array}$ & Wine & Grain & $\begin{array}{l}\text { Self- } \\
\text { effacement }\end{array}$ & Ore pits & $\begin{array}{l}\text { Defence- } \\
\text { works }\end{array}$ & In all things & Cinnamon & $\begin{array}{l}\text { Soft and } \\
\text { gentle things }\end{array}$ \\
\hline Pastimes & Games & Intrigue & Chatting & Drinking & Work & Eating & Brawling & Laziness & Sleeping & Being ill \\
\hline $\begin{array}{l}\text { Animal. } \\
\text { comparison }\end{array}$ & An elephant & Afox & A lynx & A lion & A horse & An ox & A bear & A wolf & A donkey & Acat \\
\hline Life ends & In a boat & In battle & $\begin{array}{l}\text { In a } \\
\text { monastery }\end{array}$ & In wine & In water & $\begin{array}{l}\text { On the } \\
\text { ground }\end{array}$ & In a manger & By a sword & In the snow & In fraud \\
\hline
\end{tabular}

Forts. exempe/ 3. Tabell över Europas nationer (hämtad från Goody 1997:154f.)

Tio nationer, eller nationalkaraktärer, presenteras i tabellen, och de klassificeras utifrån 17 kriterier: manners, personality, intellect osv. Det paradigmet sätts i den vänstra kolumnen och blir utgångspunkten för listningen av syntagmer där nationer jämförs. Låt oss se närmare på fransmän och tyskar. De förra är bland mycket annat fåfänga, barnsliga och varierade när det gäller de tre kriterierna manners, physical features och costume, medan tyskarna beskrivs som öppenhjärtiga, överlägsna och modeslavar.

Goody (1977:153f.) säger att människan nog har en allmän tendens att stereotypisera sina grannar. Men när detta formliaseras i en så utförlig tabell uppstår en sorts referensbok, nästan en uppslagsbok; vi får en fix och färdig guide till Europas nationalkaraktärer:

For each space in the Table has to be filled; the scheme allows of no empty boxes; the matrix abhors a vacuum. Indeed, as the looser classification of everyday speech becomes formalized in this way, the Table shifts from being a record of a classificatory system to being a kind of reference book, a ready reckoner of national character, a producer rather than just a product, comparable to the sorts of tables used by astrologers and other specialists to inform 'the man in the street' about the nature of the universe in which he finds himself.

Tabellens encyklopediska karaktär kommer sig, menar jag, av att den vilar på språkliga resurser. Som vi sett är det gärna så att tabeller (men också en del listor) kombinerar ord och siffror. Då blir, som i exempel 2 från 1200-talets Wellingford, vänsterkolumnens paradigm en 
tydlig utgångspunkt, det som något ska utsägas om. En sådan tabell blir i det närmaste ogrammatisk, i varje fall svårläst och otymplig, om inte den kategorisering som den aktuella kulturella praktiken intresserar sig för, i det fallet olika slags handlare, hamnar där. Tabellen i exempel 3 skulle principiellt kunna kastas om, så att nationaliteterna listades i vänsterkolumnen som utgångspunkt; för att få veta vad som kännetecknar en nationalkaraktär fick man då läsa horisontellt och inte vertikalt. Nu talar utrymmesskäl för den aktuella formen; det är svårt att få plats med 17 kriterier i den översta raden.

Exempel 3 pekar in mot det europeiska 1700-talet där snart sagt allt och alla kom att infogas i klassifikationssystem och taxonomier, och där en vetenskaplig rationalitet slår igenom (t.ex. Pratt 1992). Carl von Linnés Systema Naturae från 1734 är ett exempel, där djur och växter klassificeras minutiöst, och detta var också en huvudsak för den svenska Vetenskapsakademien, som grundades 1739 och med sina Handlingar startade den första svenska vetenskapliga tidskriften. Linné visade också intresse för människoraser, och indelningen av dem kom att ägnas mycket möda, inte minst under kolonialiseringen av Afrika. Genrer som naturhistoria och reseskildringar uppstod, där exotiska berättelser varvades med listartade redogörelser för klassificeringar (jfr Ledin 1997).

I Sverige grundas 1749 en myndighet med det talande namnet Tabellverket; på 1800talet döptes den om till dagens namn Statistiska centralbyrån (jfr Søbye 2014 om den norska Statistisk sentralbyrå och dess tabeller med befolkningsdata från 1735 tills idag). Befolkningsdata hade sedan länge samlats in, men nu kunde det göras än mer effektivt och med nya klassifikationssystem i det som kallades statistiska tabeller. Prästerna ålades en omfattande rapportering. Befolkningen i socken skulle redovisas inte bara till antal, utan också i relation till födda och döda, sjukdomar, märkliga händelser (formulerat som vad sällsamt i församlingen sig tilldragit haver), dödsorsaker - det sistnämnda är det som tabellen i exempel 4 är till för. Tabellen utgjorde mittensidorna i det häfte prästen fick från Tabellverket.

Av tabellen framgår, enligt summeringen längst ned till höger, att 12 personer, 8 kvinnor och 4 män, dött i Garde församling på Gotland under 1751 av följande orsaker:

- Kåppor och Mässling. Totalt 4 personer. 2 personer var av kvinnokön, båda yngre än 1 år, och 2 personer var av manskön, varav 1 person mellan 3 och 5 år och 1 person mellan 5 och 10 år.

- Heftig sjukdom och Brännsjuka. Totalt 1 person av manskön mellan 30 och 35 år.

- Mage- och Bak-ref. Totalt 1 person av kvinnokön mellan 50 och 55 år.

- Tvinsot och Mjält-sjuka. Totalt 1 person av kvinnokön mellan 35 och 40 år. (Prästen har längst till höger på tabellraden fyllt i att även 1 person av manskön dött av detta; tabellen är alltså oklar här.)

- Alderdom och Bräcklighet. Totalt 3 personer av kvinnokön, 1 mellan 75 och 80 år, 1 mellan 80 och 85 år och 1 mellan 85 och 90 år. 
- Okänd Barn-sjuka. Totalt 2 personer, båda yngre än 1 år, 1 av manskön och 1 av kvinnokön.

Det är ett omfattande klassificeringssystem vi möter. Tabellen har 32 kategorier som given information i vänsterspalten, varav sex kommer till användning i Garde. Det förutsätts att de här kategorierna ska kunna användas som en sorts diagnoser, och så sett blir de för nutida ögon lite märkliga.

Exempel 4. Statistisk tabell från Tabellverket, där prästen i Garde församling på Gotland fyllt i dödsorsaker för år 1751.

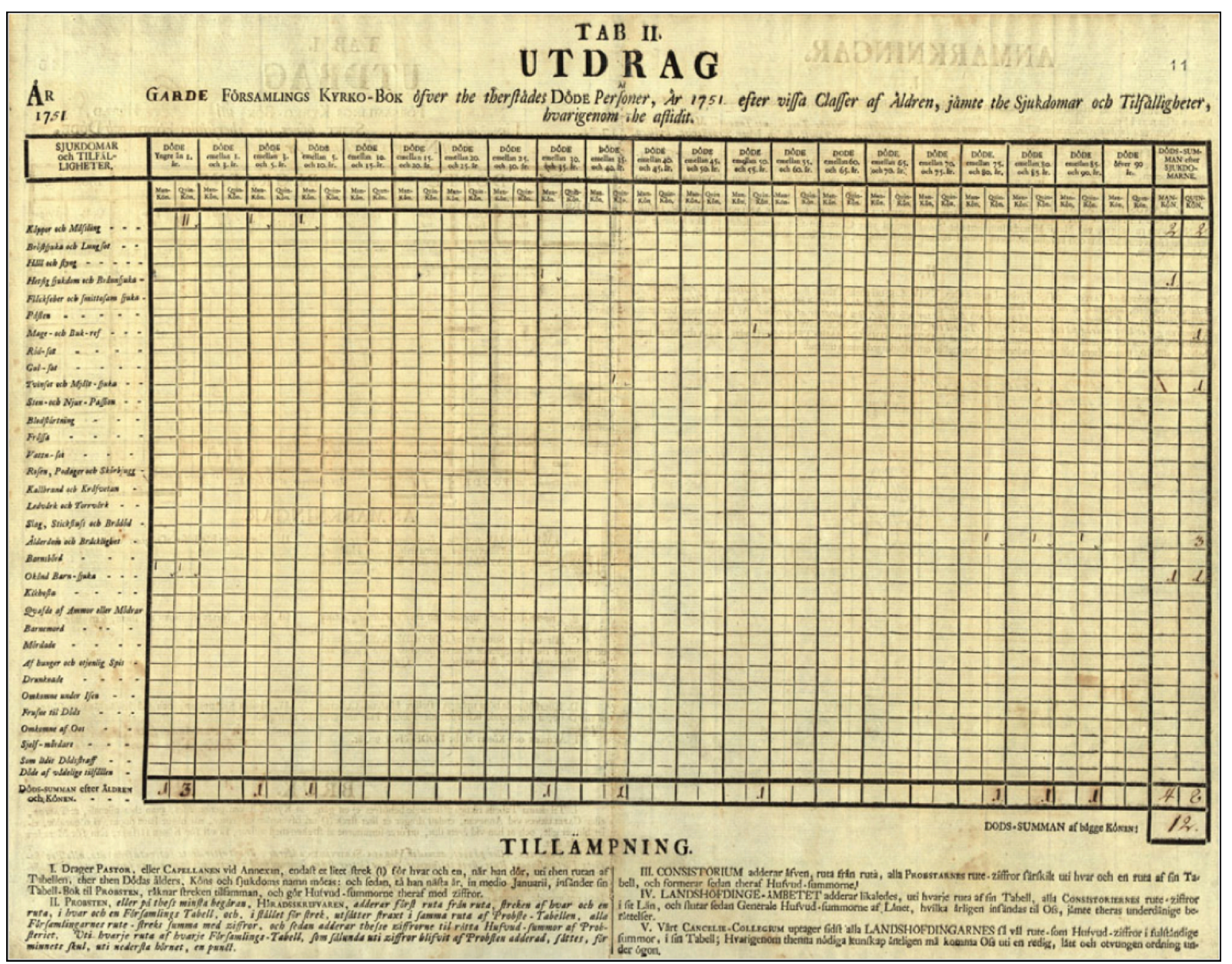

Källa: Riksarkivet, http://riksarkivet.se/Media/Bilder/Arkivnycklar/tabell-Garde-2_stor.jpg

Att lärarvetenskapen ibland famlar anar vi av kategorin Okänd Barn-sjuka. I Tvinsot och Mjält-sjuka sammanförs två olika diagnoser, och ingen av dem används idag. Tvinsot innebär förtvining, och mjältsjuka depression av något slag. Kategorin Alderdom och Bräcklighet har karaktären av en restpott, där äldre kan skrivas in. En sjukdom som cancer har ännu inte fătt någon riktig medicinsk beskrivning och saknas i tabellen. Det aktuella paradigmet etiketteras längst upp till vänster som en lista över Sjukdomar och Tillfälligheter. 
Den här tabellen skulle cirkuleras i en storskalig infrastruktur, där information som inbegrep alla människor i Sverige hanterades av olika aktörer. Vi ser instruktioner för det nederst på papperet under Anmärkningar. Där sägs vem som ska göra vad, så att den infrastruktur som informationshanteringen kräver synliggörs. Prästens tabell går till ett consortium, som börjar summera dödsorsaker i en ny tabell, vilket på nästa nivå tas över av landshöfdinge-ämbetet etc. Sådana här processer tas upp i Bowker \& Stars (1999) bok med den talande titeln Sorting Things Out. Classification and Its Consequences. En huvudsak i boken är medicinska klassifikationssystem, och den tar avstamp i en engelsk tabell för dödsorsaker från 1600-talet som i mycket liknar den senare svenska (1999:22f.).

En av många intressanta aspekter av klassifikationssystem är att de i sin utformning gör anspråk på fullständighet. Den som ska fylla i en dödsorsak eller sortera in en biblioteksbok förutsätter att det i klassificeringen av diagnoser eller bokslag finns en lämplig kategori - och om det inte riktigt finns det måste den $\mathrm{i}$ vilket fall fylla $\mathrm{i}$ en diagnos eller välja en hylla. I praktiken är klassifikationssystem - trots att vi ofta förhåller oss till dem som vore de naturliga och självklara - motsägelsefulla.

Bowker \& Star (1999) följer utvecklingen av det medicinska systemet för sjukdomsklassificering ICD, International Classification of Diseases. Det tar form i slutet av 1800-talet och utvecklas, i regi av WHO, till ett globalt system som ska innefatta alla sjukdomar på hela jorden. De diskuterar hur systemet med nödvändighet är ofullständigt och måste revideras i förhållande till olika skärningspunkter, som när generella krav på logik och fullständighet krockar med lokala kontexter, där aktörer inom forskning, politik, polisväsende, industri etc. har motstridiga intressen. I början av 1900-talet var exempelvis den mycket omfattande klassificeringen av självmord omdiskuterad. Läkare menade att den kliniskt sett var poänglös, medan politiker menade att den var viktig sociologiskt sett och för polisen. En annan diskussion var hur man vid kollektiva självmord skulle använda kategorin mord, dvs. vid vilken ålder den döda inte skulle anses vara ansvarig för handlingen utan vara tvingad till den och därmed mördad.

En poäng hos Bowker \& Star är att klassifikationssystem har olika slags materialitet. De hanteras med hjälp av papper, digitala programvaror och databaser, olika objekt osv. De återkommer till listan som ett grundläggande verktyg: "List making is foundational for coordinating activity in time and space" (1999:138). De noterar att den ökande produktionen av listor över språk, raser, minaraler, djur, sjukdomar, växter etc. var en central del av det moderna och vetenskapliga genombrottet under 1800-talet.

Exempel 4 visar hur denna utveckling nästan håller på att spränga tabellen. Eller annorlunda uttryckt: när klassifikationssystem blir komplexa och ingår i storskaliga infrastrukturer, blir det svårt att hantera allting i en enda tabell. Sjukdomstabellen har långt mer än 1000 celler. Inte bara dödsorsakerna delas in i vänsterkolumnerna, utan även högerkolumnerna har en utförlig indelning av ålder och kön för att upprätta undergrupper (totalt 42 undergrupper uppstår på detta sätt). Det är svårt att dra detta klassificeringssystem mycket längre om den form som ska användas är en enda tabell. När ICD upprättas och utvecklas kommer olika slags komplexa listor att samexistera och kodifiera olika klassifikationer och standarder. 


\section{Ontogenes: listan, tabellen och barnets utveckling}

Det är en vacker tanke att fylogenesen spelas upp i ontogenesen, att en ursprunglig utveckling hos människan som art åtminstone delvis återkommer i barnets utveckling, så att ett liknande meningsskapande tar form. En risk med den infallsvinkeln är att barns semiotiska beteenden övertolkas. Men det är, menar jag, en risk värd att ta, för det finns paralleller att göra.

Låt oss se på tidiga barnlistor. Exempel 5 visar en lapp som Doris, fyra år, gjorde när mamma höll på att skriva en handla-lista. Doris visste att det behövdes tvål och ville delta $\mathrm{i}$ den kulturella praktiken att planera matinköp. Mamma tecknade bokstäverna i luften, och Doris lade stor möda på att skriva dem så fint som möjligt med en tuschpenna på ett A4-papper, varifrån hon sedan, mycket nöjd, klippte ur den aktuella lappen och la den på köksbordet.

Liksom hos sumererna för länge sett bygger det här på korrespondens mellan tecknet och referenten, i vårt fall mellan alfabetiskt skrivna ord och en faktisk tvålförpackning. Materialiteten gör att lappen kan tas med till affären, att den blir som en etikett som rent fysiskt han häftas vid objektet. Den enkla lappen fungerar som ett externt minne som gör att aktiviteter kan koordineras över tid och rum. Typiskt för listor och deras affordances är också att de har en substantivisk karaktär om det är objekt som förtecknas. Substantiven kan, för att precisera referenten, förses med bestämningar, som extra i det här fallet.

Exempe/ 5. Doris, fyra år, bidrar till familjens handla-lista.

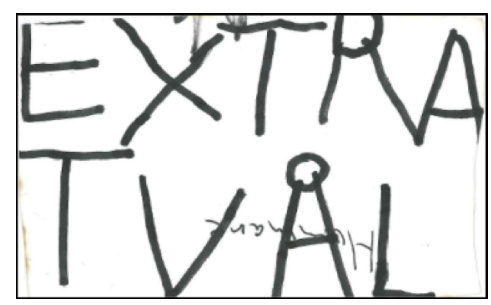

Exempel 6. Ella, sex år, skriver alfabetet i en rosa skrivbok med bård.

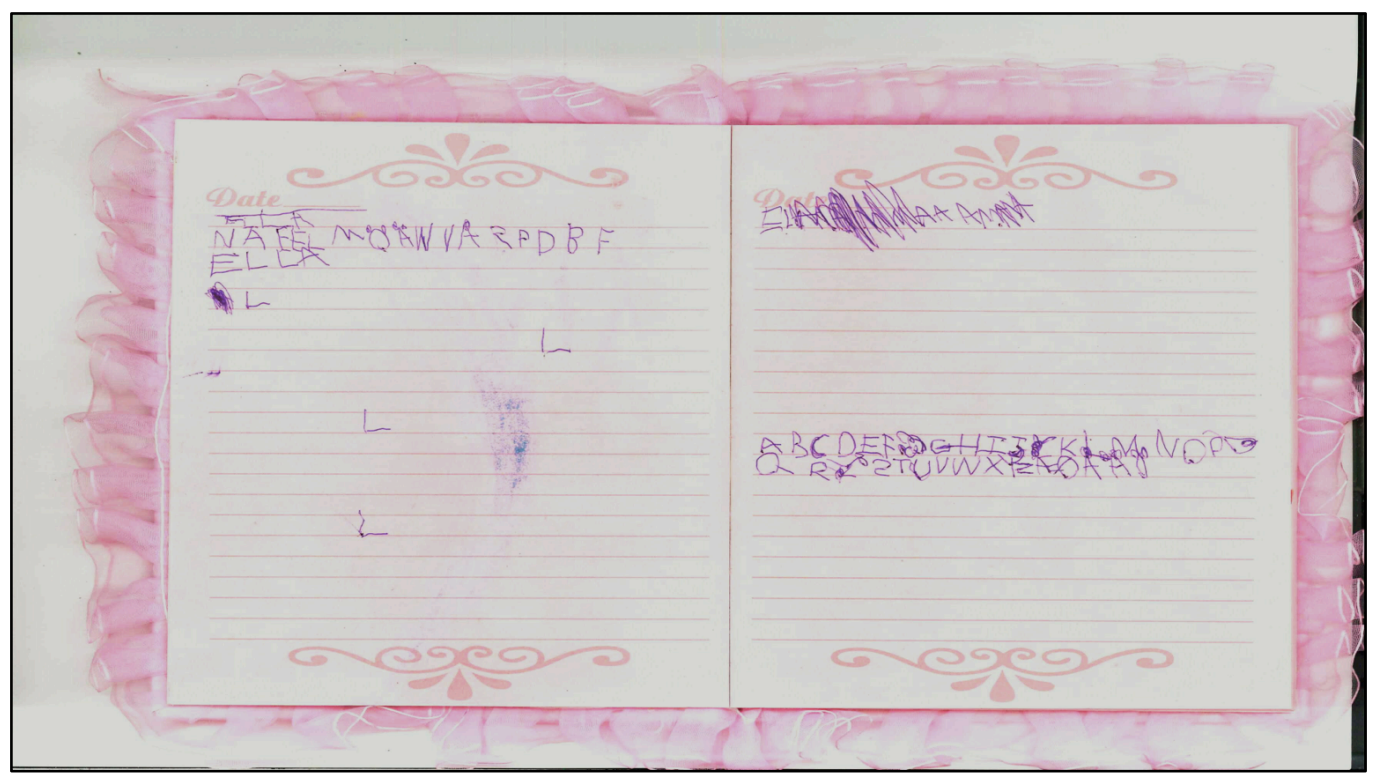


I exempel 6 har Ella, sex år, skrivit ner alfabetet. Materialiteten är en rosa skrivbok med bård runtomkring, och skrivverktyget är en bläckpenna. Här går det att göra paralleller till sumerernas lexikala listor, där skrivtecken sorterades på olika sätt. Sådana listor var, menar Goody (1977:84), viktiga i utvecklingen av det som blev alfabetet. Det Ella gör är att erövra denna "technology of the intellect" (Goody, 1968).

Det hela är inte skrivet för att kommunicera med andra, utan hon systematiserar skriftteknologin för sin egen skull och sitt eget lärande. En första bokstavsdokumentation, längst upp på sidan, är överstruken och på vänstersidan står det NÄ FEL. Skriftens kognitiva utmaningar leder ofta till att vi människor självkommunicerar (Lotman 1990) och låter externa representationer (här alfabetet utskrivet) bli interna (en förgivettagen kunskap). Detta är i linje med Vygotskijs (2001 [1934]) tes om att kognitiv utveckling sker i det sociala, i medieringar. Luria (1928:495) uttrycker det så: "If he [barnet] wishes to remember a difficult series, he invents a conventional sign, and this sign, being wedged between the task and memory, assists in the better mastering of that task."

Vi går till ytterligare en sexåring, Moa, som i exempel 7 har skrivit en matlista för sin hamster och hängt upp den på sin sovrumsdörr så att alla kan se den. I Moas familj har man haft flera hamstrar, och nu vill Moa bli en kompetent deltagare i den kulturella praktiken att ha hand om ett husdjur. Hon har därför, med familjens hjälp, förtecknat vilket slags mat som är lämplig. Listan består av substantiven jordgubbar, persilja, majs, solros(frön), jordnötter, bladpersilja, gurka, persika. Den är vertikalt utformad, vilket fungerar bra när papper är materialiteten. Då markeras tydligt den separering och abstrahering av enheter som är listformens grundidé. Återigen bygger listan på korrespondens. De paradigm som barn, liksom de gamla sumererna, utgår från är kulturellt etablerade på så vis att det rör sig om samhöriga objekt som går att peka och ta på i den aktuella listsituationen.

Det finns också korrespondens på ett annat plan, nämligen mellan piktografiska och alfabetiska tecken. Som vi ser har Moa med tuschpennor tecknat varje matvara till vänster, så att det hela får karaktären av punktlista - dessutom finns längst ner en liten tecknad hamster som rundar av listan. Dessa piktografiska tecken översätts sedan till den alfabetiska koden. Denna kombination av semiotiska resurser är det frestande att jämföra med kilskriftens och alfabetets uppkomst; de har ju sitt ursprung i avbildande, piktografiska tecken.

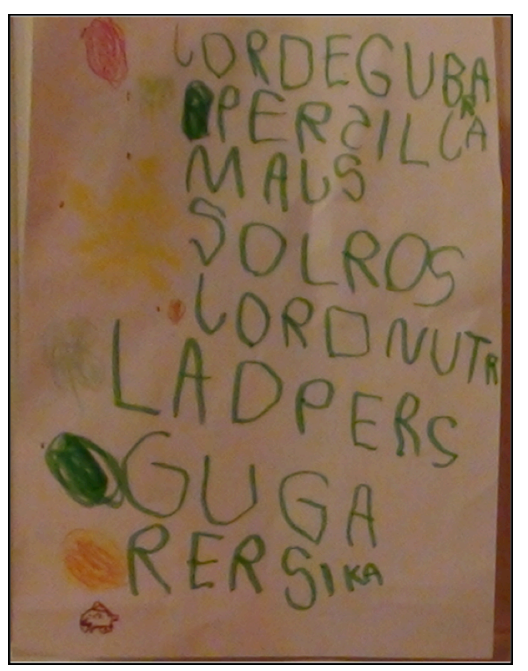

Exempel 7. Moa, sex år, har skrivit en matlista för sin hamster. 
I exempel 8 möter vi Alice, också sex år, och hennes önskelista till jul, återigen en vertikalt organiserad och substantivisk förteckning. Det är första gången Alice skriver en regelrätt önskelista, och genom utnyttja skriftens beständighet kan hon påverka presentinköp och delta i julklappsutdelningen på nya sätt. Listan ska utläsas: glassmaskin, sockervaddsmaskin, godismaskin, Barbiedocka med kläder, en egen IPad, skojlådan. Alice och mamma är båda intresserade av godis och har diskuterat detta med maskiner.

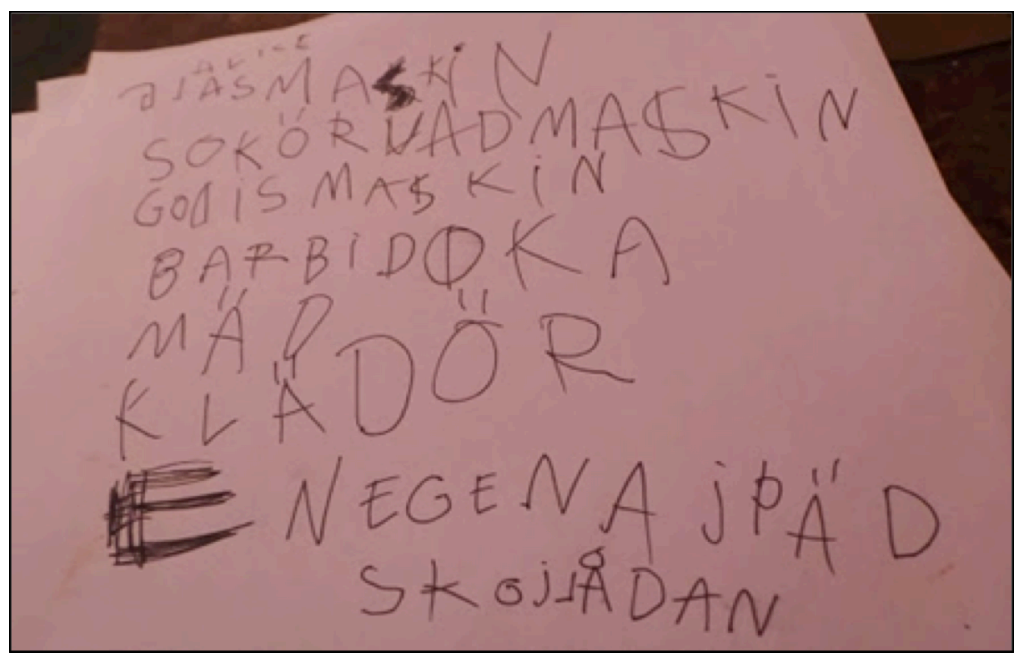

Exempel 8.

Alice, sex år, har skrivit en önskelista till jul.

En önskelista har en uppenbar framtidsdimension. Liksom handla-listan lägger den upp för att saker kan bockas av eller strykas över, så att den blir en checklista. Goody (1977:80) vill urskilja en särskild typ av lista som "serves as a guide for future action, a plan. Items get struck off, mentally or physically, as they are dealt with." Jag tror inte att framtidsdimensionen kan eller ska ses som motsvarande en avgränsad listtyp. Snarare verkar det vara en allmän egenskap hos listor att de överskrider tid och rum på sätt som tillåter planering och kontroll.

Även exempel 9 visar på hur listor hjälper till att koordinera och planera aktiviteter i tid och rum. Svea har sin kompis Siri på besök, båda är åtta år, och lillasyster Doris, som vi träffade tidigare, har nu hunnit fylla fem. Barnen går från middagsbordet eftersom de kommer på att de vill göra ett uppträdande. För att planera det behövs en lapp, tycker Svea, och skriver med en blyertspenna in sig själv som utgångspunkt eller regissör i det så kallade vänsterkrysset på det olinjerade A4-papperet. Hennes ansvar blir låtar och kläder. Eftersom personer ska skiljas ut blir det sedan lämpligt att dela in papperet som en fyrfältare, där Doris och Siri hamnar i varsin box med sina uppdrag, så att listans funktion av att separera enheter (i vårt fall personer) tydliggörs. Som vi sett behöver inte en lista vara vertikal; de tidiga sumeriska listorna hade också boxar eller celler på det här viset, och de kunde ha en syntagmatisk karaktär, så att två paradigm, här personer och uppdrag, kombineras. 


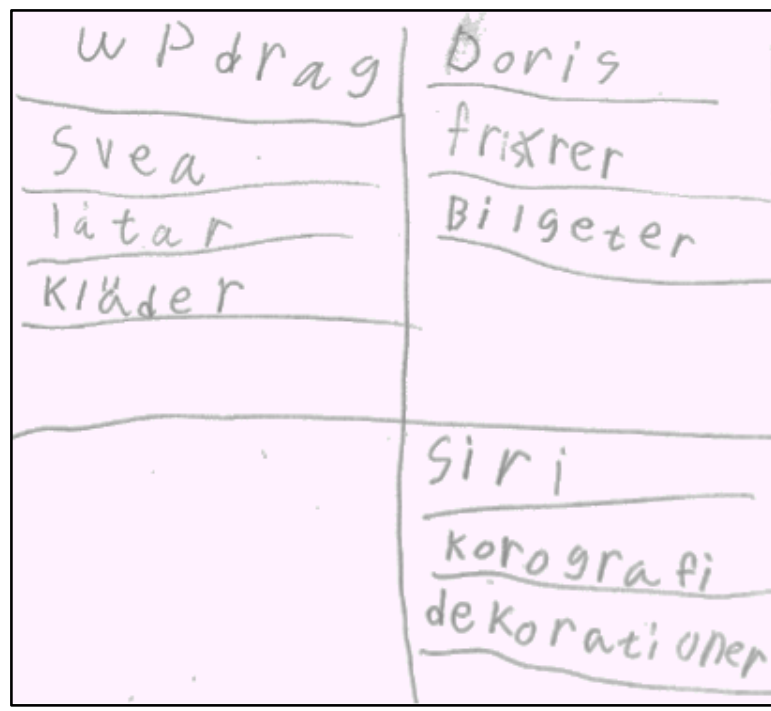

Exempel 9. Svea, åtta år, planerar ett uppträdande med den jämngamla kompisen Siri och lillasyster Doris, fem år.

Något som dyker upp hos barn och som har vissa tabellegenskaper är tidsplaneringar, som i exempel 10. Det är Sara, tolv år, som gjort vad hon kallar en "att göra-lista", en sorts schema, på ett A4-papper. Den har hon liggande på sitt skrivbord. Den syntagm som urskiljs är veckodagarna, som ordnas horisontellt i följd, som en ikonisk avbildning av tiden. Lördag och söndag hamnar i och för sig i samma kolumn, men det fungerar, eftersom det är färre aktiviteter på helgen än i veckan.

Denna syntagmatiska, tidsliga utformning tillåter Sara att överblicka stora tidssjok. Hon har lagt sig vinn om att ge listan en generisk karaktär, så att den blir ett semiotiskt verktyg som kan användas veckovis och som blir en terminsplanering. Varje dag är ett visuellt rum, som pockar på noteringar. Det blir naturligt att fylla ut dagarna och upprepa saker, och eftersom listan förtecknar handlingar blir den språkliga resurs som tas i bruk verb i infinitivform. Fixa Romeo, att ta hand om hamstern, återkommer varje dag, Städa rummet fem av veckans dagar och Välja kläder fyra av dagarna. Sara har en tendens att koda tid även vertikalt, så att dagens sista göromål, ofta att välja kläder, hamnar längst ned. Saras formatering av materialiteten skapar ett kraftfullt planeringsverktyg, men någon fullt utvecklad tabell är det inte. En sådan bygger som vi sett på att kulturellt givna paradigm eller klassifikationssystem korsas.

Exempel 10 är hämtat från Tomas Svenssons (2013) avhandling Alexander, Sara och skriften. Svensson följer två barn i 11-12-årsåldern under ett helt år med sikte på att beskriva deras skriftbruk och skriftkompetenser. Svensson har Goody (1977) som en utgångspunkt och visar att listor är grundläggande i barnens socialisation. Man skulle kunna tänka sig att Alexander och Sara läste och skrev många långa texter, kanske berättelser och ungdomsböcker, skildringar i faktaböcker eller läromedel, olika slags artiklar. Men det är sällsynt att de tar sig an sådan löpande skrift. Listor i olika former dominerar deras skriftbruk. Exempel på olika slags listor i avhandlingen kommer från digitala läromedel, diagnostiska prov, instuderingsfrågor, veckoplanering, orienterings-PM, skrift på vita tavlan, glassrecept m.m. 


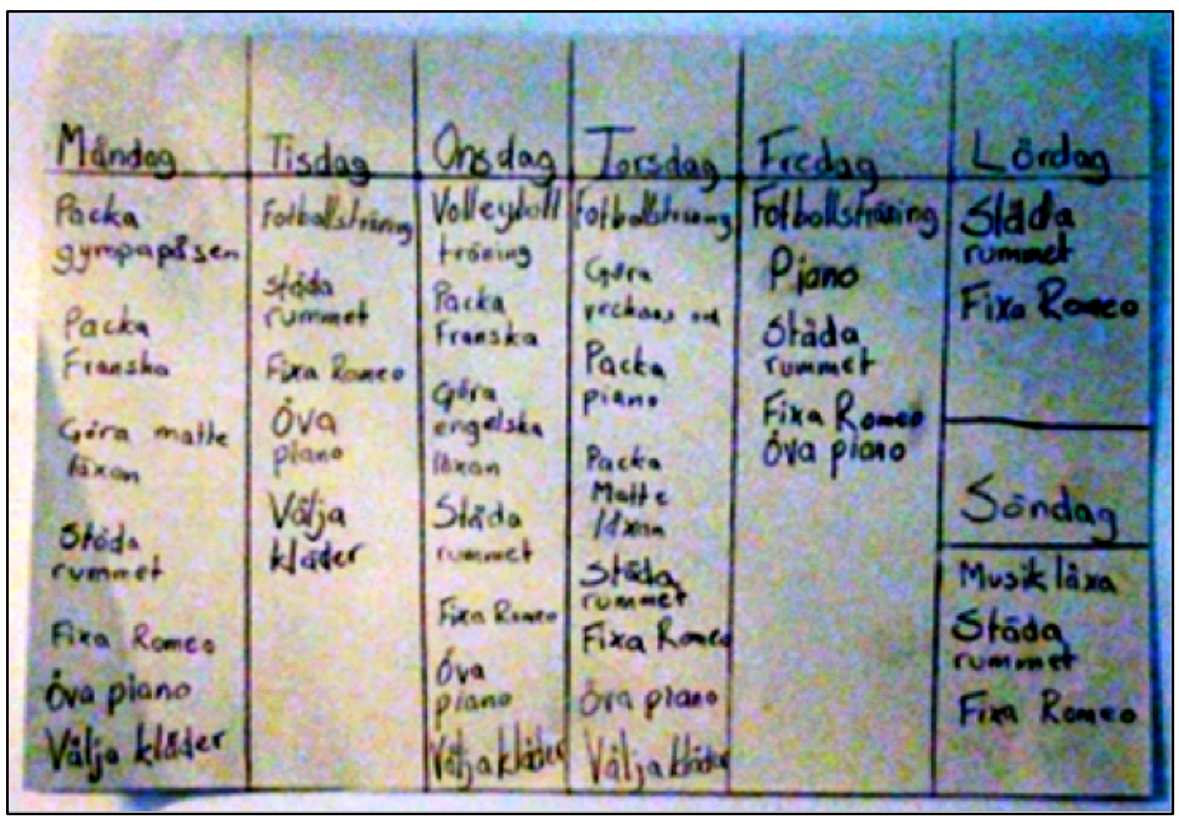

Exempel 10. Saras, tolv år, "att göra-lista", hämtad från Svensson 2013:207.

Den kunskap som skolan traderar är som regel kodifierad i något slags listform, vilket ger skolpraktikerna en encyklopedisk karaktär, där kunskapen är reifierad och snuttifierad Svensson talar exempelvis om "pincettläsning". Som Tanner (2014) visar tenderar även klassrumsinteraktionen att få listkaraktär. Geografiundervisningen om Norden i årskurs 5 kan bli sådan att elever listar möjliga svar på frågor för varandra (som på frågan "Hur försörjer sig danskarna?" på ett arbetsblad) eller att läraren genom prosodi och gester visar att han vill att elever ska lista exempel och förslag som ligger i linje med lärobokens kodifieringar (Tanner, 2014: kap. 8). Ser vi till vuxna visar sådan literacyforskning som tar sig an vanliga yrken i dagens samhälle att det är påfallande i vilken stor utsträckning skriftbruket går ut på planering, kontroll och rapportering med hjälp av listor och tabeller. Sådant skriftbruk kommer tillbaka hos lastbilschauffören, snickaren, butiksbiträdet, undersköterskan, bolagsjuristen (Karlsson, 2006; Blåsjö, 2013).

Tabeller kommer inte av sig självt i barnets skriftutveckling. De är ett avancerat semiotiskt verktyg till vars affordances, som nämnts, hör att de lämpar sig för sifferjämförelser. Tabeller införs i skolans matematikundervisning på mellanstadiet, såsom exempel 11 visar. Det kulturellt kända paradigm som är grunden för jämförelserna och som barnen ska kunna relatera till är hämtat från nöjesparker, så att åkattraktionerna på ett tivoli placeras i vänsterkolumnen. Det som kvantifieras är hur många personer, indelade i kategorierna flickor och pojkar, dvs. barn, och vuxna, som åkt under en kväll. De två frågorna till tabellen går ut på att eleverna ska kunna hantera siffrorna och jämföra vuxna med barn och attraktionerna med varandra. Att lära barn behärska tabellen som semiotiskt verktyg är en självklar del skolans literacyundervisning. 
3 På tivolit räknade man hur många personer som åkt med de olika attraktionerna under en kväll. Tabellen visar resultatet.

\begin{tabular}{|l|c|c|c|}
\hline & Flickor & Pojkar & Vuxna \\
\hline Berg- och dalbana & 69 & 82 & 122 \\
\hline Virvelvind & 74 & 61 & 70 \\
\hline Pariserhjul & 53 & 49 & 106 \\
\hline Radiobil & 51 & 54 & 62 \\
\hline Spöktunnel & 48 & 39 & 85 \\
\hline
\end{tabular}

a) I en av attraktionerna var det fler vuxna än barn som åkte. Vilken?

b) Vilken attraktion åkte flest personer med sammanlagt?

Exempel 11. Tabell med räkneuppgifter från fördjupningshäftet Mera Tornet som ingår i läromedelsserien MatteBorgen för mellanstadiet (Andersson \& Picetti, 2006:43).

Även dagens digitala värld är listberoende. Den som skriver i Microsoft Word får automatiska, förformaterade listförslag så snart programmet anar en uppräkning. Ett program som PowerPoint har punktlistan som default; det är i den formen en sida visas. Detta har för övrigt kritiserats av Kjeldsen (2009:55), som menar att listan, med dess inneboende egenskap att abstrahera och separera går på tvärs mot en levande pedagogik. Punktlistor "udelader og undertrykker [...] vigtige ræsonnementer om hvordan noget fungerer og hænger sammen. Uklarheden om hvem som gør hvad, hvordan og hvornår bliver særlig fremtrædende når brugere af programmet lader inddelingen i punkter følge af underpunkter og uoverskuelige hierarkier."

Det är typiskt att internetsökningar redovisas i träfflistor. Det är i sig fascinerande att världens kunskap numera finns digitalt lagrad på servrar och att arkivet därför inte som i det medeltida England består av noggrant förvarade pergamentrullar eller som senare av papper i arkivskåp i långa rader. Även encyklopedier och bibliotek digitaliseras. Det är också fascinerande att den listform som de gamla sumererna en gång tog i bruk fortfarande är så väl lämpad för att hantera information.

Tabellen har digitaliserats. Ett program som Microsoft Excel, som dominerar västvärldens ekonomiadministration, består av en i princip oändlig mängd celler. Cellerna ska kombineras så att paradigm och syntagmer uppstår och exakta beräkningar och jämförelser möjliggörs. Ett digitalt listprogram som blivit populärt är Trello. Programmet är interaktivt, så att användare tillsammans kan planera och organisera. Utvecklingschefen för programmet säger att idén är att kunna koppla både listor och personer till varandra på alla tänkbara sätt (Joel On Software 2012). Han jämför med Excel och konstaterar att dess tabellformat är någonting annat. Trellos listprincip fungerar för 
planning a wedding, for making a list of potential vacation spots to share with your family, for keeping track of applicants to open job positions, and for a billion other things. In fact Trello is for anything where you want to maintain a list of lists with a group of people. There are millions of things that need that kind of data structure, and there hasn't been a great "list-of-list" app before Trello.

På 5000 år har sumerernas listor på lertavlor, som fick förvaras i fysiska arkiv, blivit till ett digitalt och globalt gränssnitt där listor kan länkas till varandra i oändlighet i samspel med andra.

\section{Listans och tabellens semiotik: förslag till modell}

Jag ska, utifrån iakttagelserna ovan, föreslå en allmän modell för listans och tabellens semiotik som. Som figur 2 visar utgår jag från tre semiotiska principer för meningsskapande: kategorisering, interaktion och informationsvärde. (Principerna tangerar Hallidays beskrivning av meningsskapande utifrån metafunktionerna ideationell, interpersonell och textuell, se t.ex. Halliday \& Hasan, 1985: kap 2.)

\begin{tabular}{ll}
\hline Semiotisk princip & Realisering \\
\hline A. Kategorisering & Visuell avgränsning \\
A1. Paradigmatisk & Ett paradigm som är tillgängligt i en kulturell praktik förtecknas, vilket är \\
& listans grundform. Beroende på teckensystem och materialitet kan den \\
& visuella avgränsingen av enheter i paradigmet se olika ut. I vår kultur \\
& tenderar listor att vara vertikala och löpa uppifrån och ner. \\
& Paradigm kombineras med varandra, så att syntagmer uppstår. Detta är \\
& tabellens grundform; den utgör en syntagmatisk lista. I tabeller avgränsas \\
& och formateras ett visuellt rum systematiskt, så att det i korsningen av \\
& horisontella rader och vertikala kolumner uppstår fixeringspunkter, cel- \\
& ler.
\end{tabular}

B. Interaktion Visuell responspunkt

B1. Sluten En lista eller tabell är kodad så att visuella responspunkter saknas. Många listor har sådan karaktär, dvs. de är färdiga eller uttömmande förteckningar av ett paradigm. Också tabeller där alla celler är ifyllda saknar kodade responspunkter.

B2. Öppen En checklista eller deltagarlistas kryssrutor kodar responspunkter och är öppen för interaktion. Tabeller där celler och hela paradigm lämnas tomma kodar på samma sätt responspunkter och pockar på interaktion. 


\section{Informationsvärde Visuell placering}

C1. Given information Given information, dvs. det paradigm som tas till utgångspunkt för kategoriseringen av världen, förtecknas till vänster. Märk att distinktionen förutsätter syntagmatiska relationer, att flera paradigm kombineras och därmed kan ges olika visuell placering.

C2. Ny information Ny information, dvs. paradigm som ger ny information om det givna paradigmet, placeras till höger. Märk att distinktionen förutsätter syntagmatiska relationer, att flera paradigm kombineras och därmed kan ges olika visuell placering.

Figur 2. Semiotisk modell för listor och tabeller. Modellen förutsätter att kategoriseringar görs med hjälp av visuell avgränsning (i termer av paradigm och syntagm), att interaktion kodas med hjälp av responspunkter (i termer av sluten av öppen) och att olika informationsvärden kodas med hjälp av visuell placering (i termer av given och ny information).

Kategorisering har att göra med grundfunktionen hos listor och tabeller, att abstrahera och separera enheter från varandra i ett visuellt rum. Detta gör att enheter kodas som om de dels är ömsesidigt uteslutande, diskreta, dels har samma egenskaper, är likadana. En grundläggande affordance som kommer av detta är ett paradigmatiskt meningsskapande. Det är fenomen eller som i en kulturell praktik anses dela egenskaper som förtecknas i en lista. De språkliga resurser som tas i bruk är substantiv när listan förtecknar objekt och verb när listan förtecknar handlingar. Tabellen uppstår när det i kulturella praktiker finns ett behov av att systematiskt relatera paradigm till varandra. Då måste det visuella rummet formateras både vertikalt (ett paradigm listas) och horisontellt (flera paradigm kombineras med varandra). Tabellen blir en syntagmatisk lista, där korsningarna mellan det vertikala och horisontella blir till celler, i vilka ett ofta numeriskt innehåll fixeras exakt.

Listor och tabeller lägger upp för interaktion. De tas gärna i bruk i olika tidsrum och koordinerar sociala aktiviteter. Vitsen med att göra en handla-lista är att skapa ett externt minne som är flyttbart. Den tas med till affären, och när en vara har lokaliserats kan den posten på listan strykas (mentalt eller med en penna). En inventarielista kan på samma sätt flyttas mellan tidsrum, så att beståndet av det som förtecknas jämförs över tid. En deltagarlista kan sparas så att det vid ett senare tillfälle blir möjligt att ta en diskussion om närvaro. Tidsrummen kan också kodas som responspunkter, så att listan uttryckligen blir öppen för interaktion, vilket sker i checklistor eller deltagarlistor när kryssrutor används för att bocka av objekt eller personer. För tabeller gäller att en sådan kodning gärna blir tvingande och används för kontroll; i de celler som lämnas öppna ska saker noggrant anges. Vi har sett hur tabellen varit ett semiotiskt verktyg för att driva in skatt i 1200-talets England eller för att sammanställa alla dödsorsaker i hela Sverige under 1700-talet.

När flera paradigm ska förtecknas och materialiseras ges de informationsvärde (Kress \& van Leeuwen, 2006: kap. 6). Ett paradigm tas till utgångspunkt och blir det som något ska sägas om. I en alfabetisk skriftkultur med läsriktningen vänster till höger placeras det paradigmet till vänster. Till höger listas de paradigm som utsäger något om de givna kategorierna. 
Med andra ord är fördelningen av informationsvärde framträdande i tabeller. Där är det normalt så att ett paradigm eller klassifikationssystem uttrycks verbalt i vänsterkolumnen, varpå kolumnerna till höger ger numerisk information om de ingående kategorierna. Men även i listor kan det finnas informationsvärde, vilket har att göra med att de gärna flyttar mellan tidsrum. I en lista som är öppen för interaktion aktualiseras distinktionen mellan vad som är givet och nytt. En app som Trello är designad horisontellt för att användaren ska kunna gå från givna kategorier och genom att dra fram nya skärmbilder flytta sig till underkategorier och sedan vidare till en ruta där man markerar att något är utfört.

Den här artikeln har tagit upp listans och tabellens affordances, hur en semiotik utvecklas historiskt, i fylogenesen och ontogenesen, och betonat materialiteten hos dessa semiotiska verktyg. Att materialiteten i sig är meningsskapande betonas bland annat av Asdal m.fl. (2008:141): "I vår konkrete omgang med tekster kan en bevissthet omkring teksters materielle dimensjoner gi tilgang til en forståelse av forholdet tekst-kontekst som ikke er lukkende, som ikke behøver å fjerne oss fra teksten, men som tvert om beriker var forståelse av sammenhengene teksten inngår i."

Listan och det paradigm det förtecknar är centrala för uppkomsten av skriftkultur och kunskapsutveckling. I tidiga listor - hos sumererna för 5000 år sedan eller hos det barn som föds $\mathrm{i}$ vår kultur - bygger listorna på korrespondens mellan tecken och referent. Mat, dryck, personer, gåvor etc. som är tillgängliga i en situation och kulturell praktik förtecknas, och tecknen är från början piktografiska men blir sedan rent språkliga. Det är möjligt att ta med sig listan och fysiskt peka ut referenten, om det så är en sumerisk öltunna eller en tvål i en nutida affär.

Med tiden kommer referenterna att bli språkliga och lexikala. Det blir begrepp som förtecknas, och de ordnas och fixeras i klassifikationssystem. Detta ger med tiden upphov till ordlistor och encyklopedier, och den moderna vetenskapen är som vi sett på många sätt beroende av den systematisering av kunskap som den skrivna listan utgör. Infrastrukturer byggs upp där exempelvis ett globalt klassifikationssystem som ICD kan cirkuleras och där olika aktörer kan eller måste komma med information. Detta är också grundläggande för skolan. När sumererna uppfinner skrivkonsten måste de också uppfinna skolan, och när stora kunskapsmängder kan systematiseras och kulturellt traderas kan skolsystemet byggas ut. Det barn som kommer till dagens skola möter en encyklopedisk, listbetingad kunskap och får ta del av en literacyundervisning där behärskandet av tabeller ingår.

Min modell visar hur en historisk utveckling lett till att listor och tabeller i vår västerländska kultur lägger upp för vissa, men inte andra, sätt att skapa mening. Den säger inte hur distinktionen mellan listor och tabeller eller realiseringen av dem i andra kulturer och tider mer exakt ska förstås. Det finns också många användningar av listor och tabeller som jag inte har berört. I Ledin \& Machin (u.u.) diskuteras begränsningar i affordances hos listor, punktuppställningar och tabeller i resultatstyrningen på ett universitet, och det visar sig att dessa semiotiska verktyg kan blir ogenomträngliga eller missvisande, att det finns listor som inte, trots att det kan verka så, går tillbaka på ett etablerat paradigm eller tabeller som vid närmare betraktande inte möjliggör exakta jämförelser och därför inte är tabeller i någon rimlig mening. 
Att det finns mer att säga visar inte minst Umberto Ecos (2009) bok The Infinity of Lists. Den behandlar, som nämnts, listans estetik, dess roll i konst och skönlitteratur, med start i Homeros skeppskatalog i Illiaden. Titeln syftar inte främst på att det finns en oändlig massa listor, utan på att listan förhåller sig till oändligheten. Dess poetik har att göra med spänningen mellan det sägbara och det osägbara, mellan "everything included" och "etcetera" (s. 7), som när Dante, kommen till paradiset, inser att det inte går att räkna upp alla änglar (kap. 4). Boken är rikt illustrerad, och det är typiskt att den kommer till den kaotiska listan, detta att bringa ordning fast det inte går att bringa ordning, exemplifierat med, bland andra, en författare som Arthur Rimbaud och en konstnär som Ronald Rauschenberg (kap. 17). Min artikel har, som framgått, inte varit ute efter en poetik utan efter den semiotik som uppstår när listor börjar göras för praktiska ändamål. Med det sagt kan den som vill läsa artikeln i Ecos anda, som att människans försök att fixera tillvaron i listor riskerar att bli fåfänga, för det finns alltid detta "etcetera", något mer att lägga till - åtminstone en ny eller reviderad lista att göra.

\section{Avslutande betraktelser}

Artikeln har visat hur viktig listan är för byggandet av skriftkulturer och stater och för barns insocialisering i ett kunskapssamhälle. Den har också visat hur tabeller möjliggör en avancerad planering och kontroll. Clanchy (2013:19) introducerar sin bok om det medeltida England så här: "The main contention of From Memory to Written Record is that literacy grew out of bureaucracy, rather than from any abstract desire for education or literature”. En byråkrati, baserad på listor och arkiv, blir alltså det som ger upphov till läs- och skrivfärdighet. Bowker \& Star (1999:137) konstaterar i sin undersökning av klassifikationssystem att hantering av listor är "one of the foundational activities of advanced human society".

Det är med listan som sakprosan uppstår. Vi får sakliga förteckningar av objekt, personer, ord etc., där enheter separeras, abstraheras och reifieras. Men också sett till de konnotationer som begreppet sakprosa har och som innefattar ett avskalat innehåll, en framställning som skyr det personliga, privata eller nyckfulla, en form där det plötsliga infallet måste tyglas och inordnas i en logik. När Pipping (1938:272) myntar begreppet sakprosa gör han det genom att mota bort subjektiva uttryckssätt till förmån för objektiva: "Den objektiva stilarten är i grunden en enda. Den innefattar varje framställning där en sak behandlas för sakens egen skull - från ett matematiskt bevis till ett recept i en kokbok." Det är denna stilart som Pipping vill kalla sakprosa. Det är frestande att säga att han hänvisar till domäner och genrer som grundar sig på listor: detta gäller ju för den moderna vetenskapen, liksom för olika kok- och handböcker (jfr Nords 2010 historiska analys av trädgårdshandboken). Pippings definition har diskuterats och kritiserats i Norge och Sverige ett par decennier, men ser man det han säger som ett påstående om det som är kärnan i, eller ursprunget för, sakprosan har han en poäng (jfr Berge, 2001; Englund, Ledin \& Svensson, 2003; Tønnesson, 2012:19-22, 143).

Den visuella listan, sedd som en inskription på ett material, är ett förbluffande kraftfullt semiotiskt verktyg. Listan är dock inte unik för skriften, utan finns även i spontant tal (jfr Goody, 1977, som poängterar att skriften hämtar resurser från talet och att det leder fel att 
dikotomisera skrift och tal som medium). Karlsson (2010) visar hur talare skapar auditiva listor genom att låta syntax, prosodi och gester samverka när företeelser räknas upp. Listprosodin är ofta stiliserad, så att den tydligt avviker från det omgivande talet samtidigt som varje led i uppräkningen är prosodiskt markerat. Listor kan vara både slutna, presenterade som ett komplett paradigm, och öppna, fria för samtalspartnern att fylla på. Tretalet har uppmärksammats som en viktig form (Jefferson, 1990), även om talade listor kan ha både fler och färre led.

I talet finns alltså något av den separering och abstrahering som kännetecknar listan. Ingående led markeras som delar av en förteckning. Men i skriften görs detta visuellt och reifieras, så att enheter blir rumsligt och permanent avgränsade och listan möjlig att förvara i ett arkiv. Den kan sedan relateras till andra listor och användas för olika slags interaktion i olika tidsrum eller byggas ut till något så skriftligt som en tabell. Det är med hjälp av skrivna listor som stater blir till och en teknologi som alfabetet får sin form. Deras betydelse är svår att överskatta.

\section{Referenslista}

Andersson, P. \& Picetti, M. (2006). Mera Tornet. Del 4 i serien MatteBorgen. Stockholm: Sanoma Utbildning. Asdal, K. m.fl. (2008). Tekst og historie. A lese tekster historisk. Oslo: Universitetsforlaget.

Barthes, R. (1967). Elements of semiology. London: Cape.

Berge, K. L. (2001). ”Det vitenskaplige studiet av sakprosa”. I: Fire blikk på sakprosaen (s. 9-70). Oslo: Prosjektmiljøet Norsk sakprosa.

Björkvall, A. (2012). "Text- och resursorientering inom multimodalitetsforskningen: En teoretisk diskussion om förklaringsvärden". I: Språk \& stil. 22:1 (s. 135-161).

Blåsjö, M. (2013). "'Att skriva avtal är att förutse problem'. Medierad diskursanalys som metod för att studera bolagsjuristers textbruk.” I: Sakprosa. 5:2 (s. 1-34). Tillgänglig på https://www.journals.uio.no/index.php/sakprosa/article/view/436

Bowker, G.C. \& Star, S.L. (1999). Sorting things out: classification and its consequences. Cambridge, Mass.: MIT Press.

Clanchy, M.T. (2013). From memory to written record: England, 1066-1307. (Tredje upplagan.) Malden, MA m.fl.: Wiley-Blackwell.

Coulmas, F. (1989). The writing systems of the world. Oxford: Basil Blackwell.

Eco, U. (2009). The infinity of lists. New York: Rizzoli.

Englund, B., Ledin, P. \& Svensson, J. (2003). “Sakprosa - vad är det?”. I: Englund, B. \& Ledin, P. (red.): Teoretiska perspektiv på sakprosa (s. 35-60). Lund: Studentlitteratur.

Fernandez, R. (2001). Imagining literacy: rhizomes of knowledge in American culture and literature. Austin: University of Texas Press.

Frandsen, F., Johansen, W. \& Ellerup Nielsen, A. (1997). International markedskommunikation i en postmoderne verden. Århus: Systime.

Goody, J. (1968). “Introduction”. I: Goody, J. (red.): Literacy in traditional societies (s. 1-26). Cambridge: Cambridge University Press.

Goody, J. (1977). The domestication of the savage mind. Cambridge: Cambridge University Press.

Gärdenfors, P. (2003). How homo became sapiens: on the evolution of thinking. Oxford: Oxford University Press.

Halliday, M.A.K. \& Hasan, R. (1985). Language, context, and text: aspects of language in a social-semiotic perspective. Oxford: Oxford University Press.

Hodge, B. \& Kress, G.R. (1988). Social semiotics. Ithaca, N.Y.: Cornell University Press.

Janson, T. (1997). Språken och historien. Stockholm: Norstedt.

Jefferson, G. (1990). "List construction as a task and interactional resource". I: Psathas, G. (red.): Interaction Competence (s. 63-92). Washington D.C.: University Press of America.

Joel on Software (2012). How Trello is different. Publicerad 6/1 2012, nedladdad 2/10 2014 från http://www.joelonsoftware.com/items/2012/01/06.html 
Karlsson, A.-M. (2006). En arbetsdag i skriftsamhället: ett etnografiskt perspektiv på skriftanvändning $i$ vanliga yrken. Stockholm: Språkrådet.

Karlsson, S. (2010). "Multimodalitet i listproduktion”. I: Språk och interaktion, 2 (s. 141-170). Finska, finskugriska och nordiska institutionen. Helsingfors universitet.

Kjeldsen, J. (2009). "Billeder på væggen. Retorisk og didaktisk brug af præsentationsteknologier”. I: Adelman, K. (red.): Sjunde nationella konferensen i Svenska med didaktisk inriktning. Malmö 18-20 november 2009. Att bygga broar - kulturella, språkliga och mediala möten (s. 51-63). Malmö.

Kress, G.R. (2010). Multimodality: a social semiotic approach to contemporary communication. London: Routledge.

Kress, G.R. \& van Leeuwen, T. (2006). Reading images: the grammar of visual design. (Andra upplagan.) London: Routledge.

Ledin, P. (1997). Med det nyttiga skola wi söka att förena det angenäma... Text, bild och språklig stil $i$ veckopressens föregångare. Rapport nr 14 från projektet Svensk sakprosa. Institutionen för nordiska språk. Lunds universitet.

Ledin, P. (2013). "Den kulturella texten". I: Viden om loesning, 13: Koere genre - hvem er du? (s. 6-19).

Ledin, P. \& Machin, D. (u.u.). "How lists, bullet points and tables recontextualize social practice: a multimodal study of management language in Swedish universities". Under utgivning i Critical Discourse Studies.

Lotman, J.M. (1990). Universe of the mind: a semiotic theory of culture. London: Tauris.

Luria, A. (1928). "The problem of the cultural behavior of the child". I: Journal of Genetic Psychology, 4. Nedladdad 6/1 2013 från http://luria.ucsd.edu/Articles-by-Luria/PDFs/Luria Problem.Behavior.pdf

Melin, L. (2000). Människan och skriften: tecken, historia, psykologi. Stockholm: Norstedts ordbok.

Nasjonalbiblioteket (2012). All verdens kunnskap: leksikon gjennom to tusen år. Oslo: Forlaget Press.

Nord, A. (2010). "Flödande inspiration och praktiska råd. Om trädgårdsboken i ett läsarper-spektiv". I: Sakprosa 2:1 (s. 1-26). Tillgänglig på https://www.journals.uio.no/index.php/sakprosa/article/view/87/50

Pratt, M.L. (1992). Imperial eyes: travel writing and transculturation. London \& New York: Routledge.

Reade, J. (2000). Mesopotamia. (Andra upplagan.) London: British Museum.

Pipping, R. (1938). "Språk och stil I och II". I: Finsk tidskrift, nr 10 och 11.

Saussure, F.D. (1970 [1916]). Kurs i allmän lingvistik. Staffanstorp: Cavefors.

Svensson, T. (2014). Alexander, Sara och skriften: en skriftbruksetnografisk studie av barn i mellanåren. Diss. Örebro: Örebro universitet.

Säljö, R. (2012). Digitala medier, appifiering och arenor för lärande - från lertavlor till surfplattor. I: Skar, G. \& Tengberg, M. (red.): Svenskämnet i går, i dag, i morgon. Svensklärarföreningens årsskrift (s. 234-249). Stockholm: Natur och kultur.

Søbye, E. (2014). Folkemengdens bevegelse 1735-2014. Oslo: Oktober.

Tønnesson, J.L. (2012). Hva er sakprosa. Oslo: Universitetsforlaget.

Vološinov, V.N. (1986 [1929]). Marxism and the philosophy of language. Cambridge, Mass.: Harvard University Press.

Vygotskij, L.S. (2001 [1934]). Tänkande och språk. Göteborg: Daidalos. 